\title{
The Chemical Composition of the Nucleic Acids and the Proteins of Some Mycoplasma Strains
}

\author{
By E. T. J. CHELTON, A. S. JONES AND R. T. WALKER \\ Department of Chemistry, Birmingham University, \\ Edgbaston, Birmingham, I5
}

(Accepted for publication 7 August 1967)

SUMMARY

The base compositions of the deoxyribonucleic acid (DNA) and ribonucleic acid (RNA) of three strains of Mycoplasma laidlawii and one of Mycoplasma mycoides var. mycoides have been determined. The adenine (A) + thymine (T) content of all the samples examined was much greater than the guanine $(\mathrm{G})+$ cytosine $(\mathrm{C})$ content, the values for $\% \mathrm{GC}$ ranging from 34.4 to 32.5 for the sample of $M$. laidlawii to 30.0 for $M$. mycoides var. mycoides. The adenine + uracil/guanine + cytosine value for the RNA of all the samples was in the range $\mathrm{I} \cdot \mathrm{I} 7-\mathrm{I} \cdot 2 \mathrm{O}$.

The amino acid content of the protein of Mycoplasma laidlawii was also determined. This agrees closely with the values obtained by Sueoka (I96I) for the amino acid composition of the protein for a bacterium having the same DNA base composition.

The values given in a previous communication (Jones, Tittensor \& Walker, 1965) for the amino acid composition of the protein of Mycoplasma mycoides var. capri were incorrect since a protein fraction had precipitated from the medium during the growth of the organism because of the decrease in $\mathrm{pH}$ value of the culture which occurred. The correct values are now given and they agree closely with the values predicted from the work of Sueoka (I96I).

\section{INTRODUCTION}

In a recent compilation of the base compositions of the deoxyribonucleic acids (DNA) of bacteria (Hill, I966) which included the literature published before 1966, the analyses of the DNA of several Mycoplasma strains were listed. Most of the DNA specimens had extreme adenine + thymine (AT) compositions, the guanine + cytosine (GC) values ranging from $24 \%$ for Mycoplasma mycoides var. capri and strains from calf and young goat, to $46 \cdot 5$ for $M$. hominis.

DNA from one strain of Mycoplasma gallinarum and from one of $M$. gallisepticum have been analysed by the melting point (Tm) method and shown to have values of $28 \%$ and $32.5 \%$ GC respectively (Rogul, McGee, Wittler \& Falkow, 1965). DNA from a strain of $M$. laidlawii, $M$. pneumoniae and strains from calf and young goat were isolated and analysed by the $\mathrm{Tm}$ method and by $\mathrm{CsCl}$ density-gradient centrifugation and gave values of $3 \mathrm{I}-35.5 \%, 39-4 \mathrm{I} \%, 23.5-26.5 \%$ and $24-25.5 \%$ GC respectively (Neimark \& Pène, 1965). The wide range of these values for individual strains shows the difference obtained by the two methods of analysis and hence throws some doubt on analyses of the DNA of Mycoplasma strains done solely by physical methods, as differences in GC content of $10 \%$ as obtained here are usually 
too great to be acceptable. The values for $M$. gallisepticum DNA of $33 \%$ GC obtained by $\mathrm{CsCl}$ density-gradient centrifugation and by chemical analysis are inconsistent, as the cytosine content obtained by the latter method is some $25 \%$ lower than the guanine content, although the DNA is known to be double-stranded (Morowitz et al. 1962). The other values obtained for the DNA from $M$. gallisepticum obtained by Tm and $\mathrm{CsCl}$ density-gradient centrifugation studies agree fairly well at a value of $34-35 \%$ GC (Marmur \& Doty, I962; Schildkraut, Marmur \& Doty, 1962). The figure for $M$. hominis DNA, the GC content of which is considerably higher than that quoted for the DNA from any other mycoplasma, is questionable as the $A: T$ and $G: C$ ratios were not unity and the analysis was not performed on a pure sample of DNA (Lynn \& Smith, 1957).

In a previous paper (Jones et al. I965) we presented our findings on the nucleic acid base composition of Mycoplasma mycoides var. capri and the amino acid composition of the protein. The DNA was isolated in a pure form and gave an analysis for base composition (by the method of Wyatt \& Cohen, 1953) which was consistent with a double-stranded DNA. The composition of this DNA has also been determined by $\mathrm{CsCl}$ and $\mathrm{Cs}_{2} \mathrm{SO}_{4}$ density-gradient centrifugation and a value of $25 \% \mathrm{GC}$ was obtained in both cases (Dr W. Szybalski, personal communication) which agrees well with the value of $24.8 \%$ obtained by chemical analysis.

The present communication corrects the value obtained for the amino acid composition of the protein of Mycoplasma mycoides var. capri (Jones et al. 1965) and presents further work on the base composition of the DNA and RNA from three strains of $M$. laidlawii and one strain of $M$. mycoides var. mycoides. The amino acid composition of the protein of the strains of $M$. laidlawii is also given.

\section{Organisms}

METHODS

Mycoplasma mycoides var. capri PG 3; Mycoplasma laidlawii PG 9 and Mycoplasma mycoides, var. mycoides T 3 were obtained from Dr D. G. ff. Edward (Wellcome Research Laboratories, Beckenham, Kent). Mycoplasma laidlawii 544A and 545B were obtained from Dr P. Pease (Bacteriology Dept., The University, Edgbaston, Birmingham I5).

\section{Media}

The following media were used for growing Mycoplasma mycoides var. capri: (I) the 'normal medium' of Jones et al. (1965); (2) the 'dilute medium' of Jones et al. (1965); (3) a medium similar to the 'dilute medium' but with disodium hydrogen phosphate $(2 \%, \mathrm{w} / \mathrm{v})$ instead of the previous concentration of $0.25 \%$. The $\mathrm{pH}$ of the medium was adjusted to $7 \cdot 4$ with $0 \cdot \mathrm{I}$ N-HCl.

The following medium was used for growing Mycoplasma laidlawii: Difco-Tryptose $(2 \%, \mathrm{w} / \mathrm{v}), \mathrm{NaCl}(0.5 \%, \mathrm{w} / \mathrm{v})$, thiamine hydrochloride $\left(5 \times 10^{-4} \%, \mathrm{w} / \mathrm{v}\right)$, trihydroxymethylaminomethane $(0.5 \%, \mathrm{w} / \mathrm{v})$, glucose $(\mathrm{r} \%, \mathrm{v} / \mathrm{v})$, Difco-PPLO serum fraction $(\mathrm{I} \%, \mathrm{w} / \mathrm{v})$.

The following medium was used for growing Mycoplasma mycoides var. mycoides. Difco-beef heart infusion $(\mathrm{I} \cdot 6 \%, \mathrm{w} / \mathrm{v})$, Difco peptone $(0.3 \%, \mathrm{w} / \mathrm{v}), \mathrm{NaCl}(0.15 \%$, $\mathrm{w} / \mathrm{v})$, Burroughs Wellcome horse serum $(20 \%, \mathrm{v} / \mathrm{v})$, glucose $(\mathrm{I} \%, \mathrm{w} / \mathrm{v})$, DNA (Na salt from hymus, British Drug Houses Ltd., I \% (v/v) of $0 \cdot 2 \%(w / v))$, Difco-yeast 
extract $(10 \%(\mathrm{v} / \mathrm{v})$ of $25 \%(\mathrm{w} / \mathrm{v}))$, dipotassium hydrogen phosphate $(0.25 \%, \mathrm{w} / \mathrm{v})$, thallous acetate $(0.01 \%, \mathrm{w} / \mathrm{v})$, penicillin (I $00 \mathrm{units} / \mathrm{ml}$.).

\section{Determination of the amino acid composition of the proteins}

The organisms were grown in $\mathrm{I} \cdot 5 \mathrm{l}$. of the appropriate medium at $37^{\circ}$ for $48 \mathrm{hr}$. The organisms were harvested by centrifugation at $23,000 \mathrm{~g}$ (High speed no. I 8 Refrigerated Centrifuge, Measuring and Scientific Equipment Ltd.) for $30 \mathrm{~min}$., the organisms broken in a Mickle tissue disintegrator (H. Mickle, Mill Works, Gomshall, Surrey). for $\mathrm{I} 5 \mathrm{~min}$. suspended in a tris + magnesium buffer $\left(\mathrm{IO}^{-2} \mathrm{M}\right.$ tris, $\mathrm{IO}^{-3} \mathrm{M}$ magnesium, $\mathrm{pH} 7.3$ Io $\mathrm{ml}$.) in the presence of Ballotini beads no. 5 and the mixture dialysed against distilled water and freeze-dried. The amino acid composition of the protein of the samples was determined as previously described (Jones et al. 1965).

\section{Isolation of the nucleic acids}

(a) The organisms from Mycoplasma laidlawii strains PG 9, 544 A and 545 B after incubation at $37^{\circ}$ for $48 \mathrm{hr}$ in $\mathrm{I} \cdot 51$. of the medium detailed above were harvested at $23,000 \mathrm{~g}$. They were suspended in a mixture of phenol and sodium $p$-aminosalicylate solution $(6 \%, \mathrm{w} / \mathrm{v} ; 5 \mathrm{ml}$.) saturated with phenol (I $\mathrm{ml}$.) and broken for $\mathrm{I} 5 \mathrm{~min}$. in a Mickle tissue disintegrator in the presence of glass beads ( I ml., Junior size, $0.152 \mathrm{~mm}$. diameter; Prismo Safety corporation, Huntingdon, Pennsylvania, U.S.A.; Kolbe, 1960) with cooling (Chelton, I963). The supernatant liquid was removed from the beads, which were washed with phenol-saturated salicylate solution until the washings were clear. The combined mixture was then added to an equal volume of phenol saturated with salicylate solution and shaken for $5 \mathrm{~min}$. The layers were separated by centrifugation and the nucleic acids precipitated from the aqueous layer by adding ethanol (3 vol.). The phenol layer and any cell debris were re-extracted by shaking with more salicylate solution until no more material precipitable with 3 vol. ethanol was obtained; usually two extractions only were necessary. The combined ethanol precipitates were dissolved in water $(5 \mathrm{ml}$.) and centrifuged at $25,000 \mathrm{~g}$ (M.S.E. Major centrifuge, superspeed head) for $30 \mathrm{~min}$. to remove debris. The supernatant fluid was then made $\mathrm{M}$ with respect to $\mathrm{NaCl}$ and allowed to stand at $0^{\circ}$ for $18 \mathrm{hr}$. The precipitate was removed by centrifugation at $25,000 \mathrm{~g}$ for $30 \mathrm{~min}$., washed with $\mathrm{M}-\mathrm{NaCl}$, dissolved in water, dialysed and freeze-dried to give RNA (5-6 mg.).

The RNA and DNA were separated from any polysaccharide as previously described (Jones et al. 1965) and the DNA fractionated from the RNA by the fractional precipitation of their cetyltrimethylammonium salts at $0.6 \mathrm{M} \mathrm{NaCl}$ such that the final volume of the solution was less than $4 \mathrm{ml}$.

Owing to the small quantity of organisms obtained, the isolation procedure involved working with rather dilute solutions of nucleic acids $(<\mathrm{I} \mathrm{mg} / \mathrm{ml}$.) and thus complete separation of the DNA from RNA soluble in $\mathrm{M}-\mathrm{NaCl}$ could not be achieved by one fractionation with cetyltrimethylammonium bromide. Due to the inevitable losses at each precipitation a second fractionation could not be attempted. Thus the DNA was finally purified from RNA by digesting a solution of the nucleic acids $(2 \mathrm{mg}$. in $5 \mathrm{ml}$. of $0.0 \mathrm{I} \mathrm{M}$ acetate buffer $\mathrm{pH} 6.0$ ) with ribonuclease (0.0I $\mathrm{mg}$.) at $37^{\circ}$ for $\mathrm{I} 8 \mathrm{hr}$. The protein was denatured with chloroform, the aqueous solution dialysed against $2 \mathrm{M}$ - 
$\mathrm{NaCl}$ solution to remove the ribonuclease resistant 'core', dialysed against distilled water and freeze-dried to give DNA ( $\simeq$ I mg.).

The weights of material obtained were:

$\begin{array}{lccc}\begin{array}{c}\text { Strain of } \\ \text { M. laidlawii }\end{array} & \text { PG } 9 & 544 \mathrm{~A} & 545 \text { B } \\ \text { RNA (mg.) } & 5 & 5 \cdot 2 & 6 \\ \text { DNA (mg.) } & \text { I } & \text { I } \cdot \text { I } & \text { I } 4\end{array}$

(b) The organisms from Mycoplasma mycoides var. mycoides strain $\mathrm{T} 3$ after incubation at $37^{\circ}$ for 4 days in Io 1 . of the medium detailed above were harvested in a continuous-flow refrigerated centrifuge (M.S.E. Ltd.) at 22,00og, washed with phenolized physiological saline (phenol $0.2 \%(\mathrm{w} / \mathrm{v}), \mathrm{pH} 7 \cdot 4)$ and resuspended in phosphatebuffered physiological saline ( $\mathrm{pH} 7 \cdot 4 ; 5 \mathrm{ml}$.). This mixture was made to $6 \%(\mathrm{w} / \mathrm{v})$ with respect to sodium $p$-aminosalicylate, added to an equal volume of phenol saturated with $p$-amino salicylate solution and the nucleic acids isolated as described for $M$. laidlawii. The weights obtained were: DNA, $2.5 \mathrm{mg}$; RNA, $13.0 \mathrm{mg}$.

Base composition of the nucleic acids

These were carried out as previously described (Jones et al. 1965).

\section{RESULTS AND DISCUSSION}

Amino acid composition of the protein of Mycoplasma mycoides var. capri-A correction

In a previous communication (Jones et al. 1965) values were given for the amino acid composition of the proteins of Mycoplasma mycoides var. capri. We have since discovered that organisms harvested from growth in the dilute medium were contaminated with a protein fraction which had precipitated from the medium during growth. The dilute medium is not sufficiently buffered to prevent changes in $\mathrm{pH}$ value during growth of the organism, consequently the $\mathrm{pH}$ value decreased $(7 \cdot 4$ to $6 \cdot 4$ in normal medium, $7 \cdot 4$ to 4.9 in dilute medium) causing the precipitation of a protein fraction from the dilute medium. When the organisms were grown in medium (3) above, which is similar to the dilute medium but with added phosphate, the decrease in $\mathrm{pH}$ of the mediurn was only from $\mathrm{pH} 7 \cdot 4$ to 6.7 and no precipitation of a fraction from the medium occurred. The results of the amino acid composition of the protein of the organism (the average for the organisms grown in the normal medium and medium 3 is given as the results were almost identical) are shown in Table I. Also given are the results previously quoted (Jones et al. 1965) and the results given by Sueoka (1961) for the amino acid composition of the protein of Tetrahymena pyriformis which has a DNA with a similar base composition to that of the DNA of $M$. mycoides var. capri.

From the results in Table $I$ it can be seen that the proline content of the protein was close to the expected value as predicted from Sueoka's (I96r) results. Other experiments have indicated that the 'organisms' previously isolated from the dilute medium contained at least $50 \%(\mathrm{w} / \mathrm{w})$ of protein contaminant. It was also found that the use of a continuous-flow centrifuge (High Speed I8 Refrigerator Centrifuge, Continuous Action Rotor, Measuring and Scientific Equipment Co. Limited) for harvesting the organisms was very inefficient even with a flow rate of less than 21 ./hr. Thus only 
I $6 \mathrm{mg}$. of DNA were isolated from the organisms harvested by a continuous-flow centrifuge from 201 . of culture medium (i.e. $0.8 \mathrm{mg}$. $/ 1$.), whereas $3 \mathrm{mg}$. $/ 1$. were obtained when the organisms from an identical culture were harvested by using an angle-head centrifuge at $23,000 \mathrm{~g}$, although the $\boldsymbol{g}$ value for the two methods of centrifugation were almost identical.

\section{Table I. Amino acid composition of the total protein of Mycoplasma mycoides var. capri strain P. G. 3}

The protein was hydrolysed with $5 \mathrm{~N}-\mathrm{HCl}$ in vacuo at $110^{\circ}$ for $22 \mathrm{hr}$. The amino acid composition was determined with a Technicon Automatic Amino Acid Analyser. The results are expressed in the same form as those quoted by Sueoka (I 96I) and his values for the amino acid composition of the protein of Tetrahymena pyriformis are given for comparison. The value of the amino acid composition of the protein of $M$. mycoides var. capri when grown in two media is given: (1) the results quoted before (Jones et al. 1965); (2) the correct value which is the average of the values obtained from the cells grown in the normal medium and the dilute medium with extra phosphate. Molar amounts of amino acids, lysine, histidine, arginine, aspartic acid and asparagine, glutamic acid and glutamine, proline, alanine, valine, leucine, tyrosine and phenylalanine which are known to be stable and to be well recoverable in the analysis were summed. The other amino acids are classified as unstable amino acids. The amount of each amino acid both stable and unstable is expressed by its proportion to the sum of the stable amino acids.

Mycoplasma mycoides var. capri

$\%$ GC content of DNA.

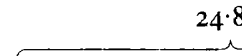

(I)

Jones et al. (1965)
$24 \cdot 8$

(2)

Present paper

Stable amino acids (average of 3 determinations)

Lysine
Histidine
Arginine
Aspartic acid
Glutamic acid
Proline
Alanine
Valine
Leucine
Tyrosine
Phenylalanine
Total

Glycine

Threonine

Serine

Isoleucine

Methionine

Cysteine

Total
$14 \cdot 0 \pm 0 \cdot 2$
$3 \cdot 0 \pm 0 \cdot 1$
$4 \cdot 3 \pm 0 \cdot 2$
I $3.4 \pm 0 \cdot 1$
$16 \cdot 2 \pm 0 \cdot 2$
II $0 \pm 0 \cdot 2$
$10 \cdot 0 \pm 0.2$
$7 \cdot 2 \pm 0 \cdot 2$
I I $8 \pm 0 \cdot$ I
$3 \cdot 6 \pm 0 \cdot 1$
$5 \cdot 5 \pm 0 \cdot 1$
$100 \cdot 0$

$$
\begin{array}{r}
14.3 \pm 0.2 \\
2.8 \pm 0.1 \\
4.0 \pm 0.1 \\
16.7 \pm 0.3 \\
15.7 \pm 0.2 \\
5.4 \pm 0.1 \\
9.9 \pm 0.2 \\
8.9 \pm 0.2 \\
12.1 \pm 0.1 \\
4.5 \pm 0.2 \\
5.6 \pm 0.1 \\
100.0
\end{array}
$$

\section{Tetrahymena pyriformis $25 \cdot 0$}

\section{Unstable amino acids}

$\begin{array}{rrr}6 \cdot 0 \pm 0.1 & 12 \cdot 8 \pm 0 \cdot 2 & \text { II.0 } \\ 6 \cdot 8 \pm 0 \cdot 2 & 7 \cdot 9 \pm 0 \cdot 2 & 7 \cdot 7 \\ 7 \cdot 3 \pm 0 \cdot 2 & 7 \cdot 3 \pm 0 \cdot 2 & 8 \cdot 1 \\ 5 \cdot 6 \pm 0 \cdot 2 & 10 \cdot 4 \pm 0 \cdot 2 & 8 \cdot 8 \\ 1 \cdot 3 \pm 0 \cdot 3 & 3 \cdot 2 \pm 0.3 & 1 \cdot 6 \\ 2 \cdot 7 \pm 0.3 & - & - \\ 29 \cdot 9 & 41 \cdot 6 & 37 \cdot 2\end{array}$

The decrease in $\mathrm{pH}$ value of the dilute medium during the growth of the organism possibly also accounted for the fact noticed previously (Jones et al. 1965), that the DNA from organisms grown in the dilute medium was always degraded unless precautions were taken to cool the medium before centrifugation. It seems probable that enzymic activity was much enhanced at $\mathrm{pH} 5$ as compared with $\mathrm{pH} 6 \cdot 4$. 


\section{Amino acid composition of the protein of Mycoplasma laidlawii}

The results for the amino acid composition of the protein of Mycoplasma laidlawii are given in Table 2 and for comparison the values given by Sueoka (196I) for the amino acid composition of the protein of Bacillus cereus which has a DNA of similar base composition to that of $M$. laidlawii. The amino acid analysis of the protein of $M$. laidlawii agrees well with the values quoted by Sueoka (196I) for the amino acid content of the protein of $B$. cereus and with those predicted from his results for a bacterium with a DNA of GC content of $33-34 \%$.

Table 2. Amino acid composition of the total protein of Mycoplasma laidlawii strains P. G. 9, $544 \mathrm{~A}$ and $545 \mathrm{~B}$

The protein was hydrolysed as given in Table $\mathbf{I}$ and the results are quoted in the same form. The results obtained by Sueoka (196I) for the amino acid composition of the protein of Bacillus cereus are shown for comparison.

Organism

Strain

$\%$ GC content of DNA

\begin{tabular}{|c|c|c|}
\hline \multicolumn{3}{|c|}{ Mycoplasma laidlawii } \\
\hline PG9 & $554 \mathrm{~A}$ & 545 \\
\hline $3 \cdot 33$ & $32 \cdot 5$ & 34.4 \\
\hline
\end{tabular}

Stable amino acids (average of 2 determinations)

Lysine
Histidine
Arginine
Aspartic acid
Glutamic acid
Proline
Alanine
Valine
Leucine
Tyrosine
Phenylalanine
$\quad$ Total

Total

Glycine
Threonine
Serine
Isoleucine
Methionine
Cysteine

Total

10.7
2.6
6.0
13.6
17.5
5.0
12.0
10.5
$11 \cdot 7$
4.9
5.5

100.0

\section{Unstable amino acids}

\begin{tabular}{rr}
$12 \cdot 0$ & $12 \cdot 8$ \\
$8 \cdot 4$ & $7 \cdot 9$ \\
$7 \cdot 3$ & $7 \cdot 1$ \\
$8 \cdot 5$ & $9 \cdot 1$ \\
$3 \cdot 1$ & $2 \cdot 9$ \\
\hline
\end{tabular}

$39 \cdot 3$
II. $4 \quad 1$ I I

$2 \cdot 8$

6.0

$14 \cdot 4$

$16 \cdot 2$

$5 \cdot 4$

$10 \cdot 8$

II. O

$12 \cdot 3$

$4 \cdot 7$

$5 \cdot 2$

$100 \cdot 0$

$39 \cdot 8$

$3 \cdot 2$
$6 \cdot 3$

13.4

$17 \cdot 2$

5.0

$11 \cdot 6$

$10 \cdot 3$

II 8

$4 \cdot 9$

$5 \cdot 2$

100.0

$39 \cdot 9$

\author{
Bacillus \\ cereus \\ ATCC 6464 \\ $35^{\circ} \mathrm{O}$
}

$10 \cdot 4$
$2 \cdot 9$
$5 \cdot 9$
$12 \cdot 7$
$17 \cdot 4$
$4 \cdot 9$
$14 \cdot 6$
$10 \cdot 7$
$11 \cdot 6$
$3 \cdot 8$
$5 \cdot 0$
$99 \cdot 9$

$\begin{array}{rr}12 \cdot 4 & 13 \cdot 7 \\ 8 \cdot 3 & 7 \cdot 9 \\ 7 \cdot 1 & 6 \cdot 1 \\ 8 \cdot 4 & 8 \cdot 4 \\ 3.4 & 4 \cdot 0 \\ - & 0.5\end{array}$

39.0

No attempt was made to determine the amino acid composition of the protein of Mycoplasma mycoides var. mycoides because (a) with the large amount of horse serum in the medium it was very likely that some precipitation of a serum protein fraction would occur; $(b)$ as such a small quantity of organisms was obtained from such a large volume of medium, any small amount of precipitate from the medium would involve a considerable percentage error in the amino acid composition of the protein, and it was therefore thought that no reliance could be placed on the results.

Composition of the nucleic acids

The base compositions of the DNA and RNA are shown in Tables 3 and 4 respectively. 
Table 3. Base composition of the DNA of Mycoplasma laidlawii strains P. G.9, $544 \mathrm{~A}$ and $545 B$ and $M$. mycoides var. mycoides strains $T 3$

The amounts of bases present were determined from the ultraviolet absorption of the eluate from paper chromatograms after hydrolysis of the DNA with formic acid. The amounts are given in moles base/100 g. atoms P.

\begin{tabular}{|c|c|c|c|c|c|}
\hline Species & $\begin{array}{c}\text { Guanine } \\
\text { (G) }\end{array}$ & $\begin{array}{l}\text { Adenine } \\
\text { (A) }\end{array}$ & $\begin{array}{c}\text { Cytosine } \\
\text { (C) }\end{array}$ & $\begin{array}{c}\text { Thymine } \\
\text { (T) }\end{array}$ & $\frac{A+T}{G+C}$ \\
\hline M. laidlawii $\mathrm{PG} 9$ & $16 \cdot 3$ & $33 \cdot 0$ & $17 \cdot 0$ & $33 \cdot 7$ & $2 \cdot 00$ \\
\hline M. laidlawii 544A & $15 \cdot 7$ & $33 \cdot 2$ & 16.8 & $34 \div 3$ & $2 \cdot 08$ \\
\hline M. laidlawii 545 в & 17.0 & $32 \cdot 8$ & $17 \cdot 4$ & $32 \cdot 8$ & $I \cdot 9 I$ \\
\hline M. mycoides var. & $15 \cdot 2$ & $35 \cdot 5$ & $14 \cdot 8$ & $34 \cdot 5$ & $2 \cdot 33$ \\
\hline
\end{tabular}

Table 4. Base composition of the RNA of Mycoplasma laidlawii strains

P. G. 9, $544 A$ and $545 B$ and $M$. mycoides var. mycoides $T 3$

The amounts of bases present were determined from the ultraviolet absorption of the eluate from paper chromatograms after hydrolysis of the RNA in hydrochloric acid. The amounts are given in moles base/ $100 \mathrm{~g}$. atoms $\mathbf{P}$.

\begin{tabular}{|c|c|c|c|c|c|c|}
\hline Species & $\begin{array}{l}\text { Guanine } \\
\text { (G) }\end{array}$ & $\begin{array}{l}\text { Adenine } \\
\text { (A) }\end{array}$ & $\begin{array}{l}\text { Cytosine } \\
\text { (C) }\end{array}$ & $\begin{array}{l}\text { Uracil } \\
\text { (U) }\end{array}$ & $\frac{A+U}{G+C}$ & $\frac{G+U}{A+C}$ \\
\hline M. laidlawii $\mathrm{PG} 9$ & $27 \cdot 0$ & $30 \cdot 5$ & $19 \cdot 0$ & 23.5 & $1 \cdot 17$ & $1 \cdot 02$ \\
\hline M. laidlawii 544A & $26 \cdot 0$ & $31 \cdot 0$ & 19.5 & 23.5 & $I \cdot 20$ & 0.98 \\
\hline M. laidlawii 545 B & $26 \cdot 7$ & 30.5 & 19.0 & $23 \cdot 7$ & $I \cdot I 8$ & $1 \cdot 02$ \\
\hline $\begin{array}{l}\text { M. mycoides var. } \\
\text { mycoides } \mathrm{T} 3\end{array}$ & $26 \cdot 4$ & $3 I \cdot 0$ & $19 \cdot 4$ & 23.2 & $I \cdot I 8$ & 0.99 \\
\hline
\end{tabular}

It is noteworthy that the base composition of the DNA of Mycoplasma laidlawii given in the present paper lies within the range of values previously obtained and that the DNA from the two species of Mycoplasma analysed here are both of the extreme AT type, thus indicating the possibility that the mycoplasmas may be closely related. It would be of interest to attempt DNA/DNA hybridization between mycoplasmas to see whether the similarity in base composition is matched by a similarity in base sequence. The only work of this type to have been reported is on the hybridization between the DNA of a mycoplasma and its supposedly related bacterium; no DNA homology was demonstrated (Rogul et al. 1965).

The base compositions of the RNA of the two species of mycoplasma are very similar to those previously determined for Mycoplasma mycoides var. capri. The $\mathrm{A}+\mathrm{U}: \mathrm{G}+\mathrm{C}$ ratios are in the range $\mathrm{I} \cdot 17-1 \cdot 20$ and the moles of 6 -amino bases are equal to the moles of 6-keto bases.

We wish to thank Professor M. Stacey for his interest, Dr D. G. ff. Edward and Dr R. H. Leach (Wellcome Research Laboratories) for supplying Mycoplasma mycoides var. mycoides organisms and for helpful discussions, and the British Empire Cancer Campaign (Birmingham Branch) for financial assistance. 


\section{REFERENCES}

Chelton, E. T. J. (1963). Preventing temperature rise during the mechanical breakage of microorganisms. J. appl. Bact. 26, 178.

HiLl, L. R. (1966). An index to deoxyribonucleic acid base compositions of bacterial species. J. gen. Microbiol. 44, 419.

Jones, A. S., Tittensor, J. R. \& Walker, R. T. (1965). The chemical composition of the nucleic acids and other macromolecular constituents of Mycoplasma mycoides var. capri.J. gen. Microbiol. 40, 405 .

KolBE, J. J. (I960). Avoidance of alkaline effects in cell disruption by glass beads. Biochim. biophys. Acta, 38, 373.

LYNN, R. J. \& SMTTH, P. F. (1957). Nucleic acid content of pleuropneumonia-like organisms from human sources. J. Bact. 74, 8 I I.

Marmur, J. \& Doty, P. (1962). Determination of the base composition of deoxyribonucleic acid from its thermal denaturation temperature. J. molec. Biol. 5, Io9.

Morowitz, H. J., Tourtellotte, M. E., Guild, W. R., Castro, E., Woese, C. \& Cleverdon, R. C. (1962). The chemical composition and sub-microscopic morphology of Mycoplasma gallisepticum, Avian PPLO 5969. J. molec. Biol. 4, 93.

NeimaRK, H. C. \& PÈNE, J. J. (1965). Characterization of pleuropneumonia-like organisms by deoxyribonucleic acid composition. Proc. Soc. exp. Biol. Med. I18, 517.

Rogul, M., MCGee, Z. A., Wittler, R. G. \& Falkow, S. (I965). Nucleic acid homologies of selected bacterial, L. forms and Mycoplasma species. J. Bact. 9o, I200.

Schildkraut, C. L., Marmur, J. \& Doty, P. (1962). Determination of the base composition of deoxyribonucleic acid from its buoyant density in CsCl. J. molec. Biol. 4, 430.

SuEOKA, N. (196I). Correlation between base composition of deoxyribonucleic acid and amino acid composition of protein. Proc. natn. Acad. Sci. U.S.A. 47, II4I.

WyatT, G. R. \& COHEN, S. S. (1953). The bases of the nucleic acids of some bacterial and animal viruses: the occurrence of 5-hydroxymethyl cytosine. Biochem. J. 55, 774 . 